Despite many lengthy reviews in recent years and a number of conferences devoted exclusively to this subject the natural history of the disease is still not clearly understood.

Sir Geoffrey Keynes has condemned the "occasional thyroidectomist," and there is no doubt that the incidence of complications is higher in the hands of surgeons who are not constantly performing thyroid operations. Total thyroidectomy should be carried out at present only by those with plenty of experience in this field. Whenever possible, total thyroidectomy should be done in those centres where isotope facilities are well provided, so that the ancillary methods of investigation and treatment are available.

1 Woolner, L. B., Beahrs, O. H., Black, B. M., McConahey, W. M., and Keating, F. R., in Thyroid Neoplasia, ed. S. Young and D. R. Inman, p. 51. London, Academic Press, 1968.

2 Russell, W. O., Ibanez, M. L., Clark, R. L., and White, E. C., 1963. Cancer (Philadelphia), 16, 1425.

3 Crile, G., Jr., American fournal of Surgery, 1964, 108, 862.

Thompson, N. W., and Harness, J. K., Surgery, Gynecology and Obstetrics, $1970,131,861$.

${ }^{5}$ Davis, R. H., Fourman, P., and Smith, J. W. G., Lancet, 1961, 2, 1432.

- Michie, W., Stowers, J. M., Frazer, S. C., and Gunn, A., British Fournal of Surgery, 1965, 52, 503 .

7 Wade, J. S. H., British fournal of Surgery, 1960, 48, 25.

- Blackburn, G., and Salmon, L. F. W., British fournal of Surgery, 1961, 48, 371 .

Taylor, S., British fournal of Surgery, 1965, 52, 740.

\section{A Case of Confidence}

In dismissing the charge against Dr. R. J. D. Browne heard by the G.M.C.'s Disciplinary Committee the President emphasized that its decision related to the particular circumstances of the case. Nevertheless the decision is of general importance because it upheld the principle of medical practice that the doctor has an obligation to act in the way he judges to be in the best interests of his patient. At the same time the judgment reaffirms the position of the family doctor in his relationship to the individuals in his care. A report of the case is published this week in the Supplement at page 79.

Dr. Browne was charged with improperly disclosing to the father of a girl then aged 16 that she had been prescribed an oral contraceptive by Birmingham Brook Advisory Centre "notwithstanding that he had been given this information in confidence by the Centre and that he had neither sought nor received her permission to make this disclosure." It was because of a complaint from the Centre that the charge was brought. And clearly the Centre acted as it did in the case of a patient who was in the care of another doctor because it feared that the effect of the disclosure to the girl's parents might deter other girls from seeking its help. Dr. Browne for his part explained in his evidence why he informed the girl's parents that she had been prescribed the pill, and in essentials his argument was that, as her doctor and as the family's doctor, he considered a different treatment of the situation would be in the girl's best interests.

In acting, as he believed, for the benefit of his individual patient Dr. Browne was therefore fulfilling the doctor's traditional role. Once other considerations are allowed to enter this relationship between doctor and patient, whether they spring from the explicit recommendations of another doctor, the supposed needs of the community, or the declared requirements of the State, the doctor must be immediately on his guard. Pressures of this kind are now numerous and plausible to an extent hardly imagined two decades ago, and it would be tragic if in ministering to the needs of the community medical men ever allotted second place to the needs of the individual. While it is exceedingly important that women of any age should not be deterred from seeking the best medical advice, the supposition that any might be deterred cannot be allowed to prevent a doctor from doing what he considers best for an individual patient.

If conflict of this kind is to be avoided in the sphere of family planning, or for that matter plain contraception for the unmarried, the procedure at the clinics offering advice and prescribing contraceptives needs to be thought out with some care. This is particularly true now that the pill is prescribed, for despite a tendency in some quarters to play down the side effects of oral contraceptives there is no doubt they must be taken seriously. The most disastrous of them, severe thromboembolism, is fortunately rare, but it is becoming evident that pathological depression is commoner than was originally thought, affecting about 1 in 20 women on the pill. ${ }^{12}$ There may also be a slight risk of inducing hypertension at least temporarily. $^{3}{ }^{4}$ But whatever the size of these hazards, the need to take every precaution against exposing a patient to them needlessly must surely impose a requirement on a doctor prescribing the pill to obtain information first from the woman's general practitioner. A strong family history of thrombosis or depression, for instance, might be relevant to the advice offered the woman, as might the woman's own medical history, which is not always clearly recalled at an interview with a strange doctor. These ordinary principles of clinical medicine are still generally accepted and have been interpreted in a statement on medical ethics in relation to family planning clinics as follows: "The woman's own doctor should always be given an opportunity to express an opinion before an oral contraceptive is prescribed or an intrauterine contraceptive device fitted."5 Any general departure from advice so firmly founded on the traditional principles of medical practice would be unfortunate. The statement goes on to say that, if the treatment is carried out without the prior consent of the patient's own general practitioner, doctors prescribing either of these forms of contraception "shall remain, in that respect, responsible for the future management of the patient." In many circumstances this must seem to represent an uneasy compromise and sometimes to be impracticable. Surely, since there are various contraceptive methods available, a clinic doctor should not prescribe one of those carrying a distinct hazard without the consent of the woman's own doctor. For as well as being the person best able to give advice from his knowledge of the woman and her medical background he must in the ordinary way be the person most likely to be called in if a complication follows.

Consulting the family doctor before prescribing the pill rather than informing him afterwards as well as being good medicine also had a bearing on the issue of confidentiality laid before the Disciplinary Committee. The Brook Advisory Centre claimed that it had given the information to Dr. Browne in confidence, and the Committee accepted that view. In fact as a general rule the transmission of information about patients between doctors would be impossible if they did not regard it as strictly confidential. But in this case the family doctor disagreed with the approach already taken at the clinic to the girl's problem, and his discussing it with her parents seemed to him essential to her welfare despite what the Disciplinary Committee ruled to be a disclosure, but not an improper one, of confidential information. Again it is worth drawing attention to the special emphasis laid by the President in the Committee's ruling on the particular circumstances of this case. No general principle except the primacy of the 
doctor's professional judgment in assessing his patient's needs is at stake here, and the ruling does not in any way mean a relaxation in the bonds of confidence that exist between doctor and patient.

1 British Medical fournal, 1970, 4, 127.

2 Herzberg, B. N., Johnson, A. L., and Brown, S., British Medical fournal, $1970,4,142$.

${ }^{3}$ British Medical fournal, 1970, 2, 378.

4 Weir, R. J., et al., Lancet, 1971, 1, 467.

Members Handbook, London, British Medical Association, 1970.

\section{Treatment of Habitual Drunken Offenders}

The report of the Home Office working party on habitual drunken offenders ${ }^{1}$ is a major review of a much neglected social problem. Though chary of proposing a solution, the working party has come up with a set of proposals which, if carried out, would do much to make society's response to the man or woman drunk in the street more humane and more rational. For the continuance of the present revolving door system, which pushes the drunk repeatedly and aimlessly through court and prison, the report could find no one in favour-policemen, magistrates, prison officers, and social workers all shared the unanimous view that the present system is a degrading, expensive, and ineffectual absurdity.

The report does not envisage any one new type of treatment as holding the magic answer, but insists rather that the task is to design a system of integrated care by statutory and voluntary agencies. But within this system an important place would be given to new emergency treatment units, which would be called detoxification centres. A man who was publicly drunk would still be charged and picked up by the police, but he would be taken to such a centre rather than to the police cell, and the charge would usually later be dropped. At this centre an inebriate could initially be held for 72 hours, but on the signature of two doctors a further seven-day order could be made. The centre's job would be not only the immediate one of detoxification and physical care, but would also include full assessment of social needs and the planning of aftercare, in which specialized alcoholism hostels would play a major part.

That society should today be taking the problem of the habitual drunkenness offender seriously results from the coincidence of several very different factors. Firstly, there has been the need to relieve overcrowding in prisons and the strain on the courts. In 1968 there were 2,719 receptions of men and 206 receptions of women into prison for drunkenness offences, ${ }^{2}$ while at any one time between 100 and 200 prison places were occupied by such cases. On an average day the police and the courts deal with more than 200 public drunkenness offences. Another stimulus for change has been the growing body of research which has followed on from the pioneering work of M. M. Glatt and J. S. Whiteley ${ }^{3}$ and of D. Parr, ${ }^{4}$ which has shown that the typical drunkenness offender-far from conforming to the popular stereotype of the happy roisterer-is most usually someone heavily addicted to alcohol ${ }^{5}$ and deserving of the label "alcoholic." Research has also shown the extreme degree to which these people are socially isolated; they are usually without jobs, homes, or close human contacts. An experimental skid row hostel in London $^{6}$ has proved that rehabilitation is a real alternative to repeated gaol sentences, while successful experiments with detoxification centres in Eastern Europe and the U.S.A. must also have been a spur to change. In America the contention that the drunk is ill rather than deserving of punishment was fought all the way up to the Supreme Court, and then the case was lost only because no real alternative to imprisonment seemed to hand. Avoiding the American dilemma, the Criminal Justice Act of 1967 invited new thinking on drunkenness by an enabling clause (Section 91) which would substitute alternatives to imprisonment for drunk and disorderly when (and only when) the Home Secretary of the day was satisfied that alternative facilities really existed. An important international conference held in London in 1968 brought many matters into focus, ${ }^{7}$ and the personal commitment of a reforming Under Secretary of State-Lord Stonham-set the working party on its task.

Given the report, how are any of its ideas to be realized? The last major review of the country's drunkenness problem was undertaken in 1834, and that Select Committee recommended among other measures the abolition of the Navy's rum ration: the recommendation was followed in 1970. We should heed that cautionary tale. The present working party's report is in fact weak when it comes to the practicalities of action, and seems rather piously to hope that vastly complex organisational problems need be matched by no very special or imaginative efforts. Nevertheless, "co-ordination" must become more than a hopeful slogan. The Department of Health is presumably going to share some partnership with the Home Office, despite the working party's restricted terms of reference, which supposedly limited its attention to "treatment within the penal system," and a host of voluntary organizations with strong traditions of individuality are also going to have to be brought into the scheme. Moreover, even then much more than the right committee structure will be needed: people with conviction and energy and mobile teams willing to travel. The demand is for expansion of specialized hostel places from 92 at the end of 1969 to an eventual 5,000, and of detoxification beds from zero to something over 500 . The way ahead will not be easy.

\footnotetext{
1 Habitual Drunken Offenders. London, H.M.S.O., 1971 (see B.M.F., 1971,

1, 617)
Home Office, Report of the Work of the Prison Department. Statistical Tables for 1968. (Cmnd. 4266), London, H.M.S.O., 1970.

${ }^{3}$ Glatt, M. M., and Whiteley, J. S., Monatsschrift für Psychiatrie und Neurologie, 1956, 132, 1.

- Parr, D., British fournal of Criminology, 1962, 2, 272.

5 Gath, D., Hensman, C., Hawker, A., Kelly, M., and Edwards, G., British Medical fournal, 1968, 4, 808.

- Cook, T., Morgan, H. G., and Pollak, B., British Medical Fournal, 1968, 1,240 .

- Proceedings of an International Symposium on the Drunkenness Offence, ed. T. Cook, D. Gath, and C. Hensman. London, Pergamon, 1969.
}

\section{Antibacterial Agents in Renal Failure}

A patient with poor renal function faces two risks when he has to be treated with a drug which is mainly excreted by the kidney. Firstly, there is the danger of toxicity resulting from a high blood concentration secondary to the impaired excretion; and, secondly, there is the equally important risk of his being denied necessary treatment because of the fear of this consequence. Certainly, it is wise to avoid all but essential drugs in these patients, but none need be denied them provided that the dose is appropriately modified.

The principles of drug dosage in renal failure have been discussed by $C$. $M$. Kunin and $M$. Finland. ${ }^{1}$ If a drug is stable in plasma and eliminated from the body entirely by 